\title{
Analisis Perbandingan Metode Muller dan Metode Birge-Vieta dalam Menyelesaikan Persamaan Polinomial
}

Try Azisah Nurman

Universitas Islam Negeri Alauddin Makassar, try.azisah@uin-alauddin.ac.id

\begin{abstract}
ABSTRAK, Penelitian ini membahas tentang menyelesaikan permasalahan-permasalahan persamaan polinomial dengan perbandingan penyelesaian persamaan polinomial menggunakan metode Muller dan metode Birge-Vieta dengan bantuan Program $\mathrm{R}$ berdasarkan akar, galat terkecil, iterasinya dan waktu komputasi. Persamaan polinomial merupakan persamaan yang sering ditemui pada banyak analisis problem. Persamaan yang digunakan penulis pada penelitian ini meggunakan persamaan berderajat 4 yaitu $f(x)=x^{4}-$ $8 x^{3}-36 x^{2}+462 x-1010$, persamaan berdejat 5 yaitu $f(x)=x^{5}-3.7 x^{4}+7.4 x^{3}-10.8 x^{2}+10.8 x-$ 6.8 , persamaan berderajat 6 yaitu $f(x)=0.0004 x^{6}-$ $0.0156 x^{4}+0.25 x^{2}-1$ dan persamaan berderajat 7 yaitu $\quad f(x)=x^{7}-28 x^{6}+322 x^{5}-1960 x^{3}-$ $13132 x^{2}+13068 x-5040$. Hasil penelitian menunjukkan pada metode Muller membutuhkan iterasi yang sedikit dan memperoleh akar berubah akar real dan komplek, tetapi galatnya masih besar dan membutuhkan waktu komputasi yang panjang, sedangkan pada metode Birge-vieta membutuhkan iterasi yang lebih banyak dan akar yang diperoleh berupa akar real saja, tetapi galatnya kecil dan membutuhkan waktu komputasi yang lebih sedikit.
\end{abstract}

Kata Kunci: Persamaan Polinomial, Metode Numerik, Metode Muller, Metode Birge-Vieta, Program R

\section{PENDAHULUAN}

Matematika merupakan salah satu alat bantu untuk menyelesaikan suatu masalah biasanya berupa perumusan. Artinya suatu masalah dapat diselesaikan apabila sudah dirumuskan ke dalam bahasa matematika yang dinyatakan dalam bentuk simbol-simbol. Seringkali model matematika yang rumit ada kalanya tidak dapat diselesaikan dengan metode analitik untuk mendapat penyelesaian akhir yang sebenarnya. Jika persoalanpersoalan yang di hadapi tidak dapat diselesaikan dengan metode analitik, dalam menganalisis suatu permasalahan yang didekati dengan menggunakan metode numerik. Salah satu penerapan metode numerik dalam perhitungan aritmetika adalah mencari akarakar persamaan polinomial.
Ada beberapa metode numerik yang dapat digunakan untuk menentukan atau mencari akar-akar persamaan polinomial antara lain metode newtonp-raphson, metode bagi dua, dan metode regula falsi Akan tetapi, metode tersebut dianggap belum cukup untuk mencari penyelesaian dari persamaan polinomial, karena penyelesaian yang dihasilkan hanya berupa akar real. Dalam menyelesaikan suatu persamaan polinomial terkadang penyelesiannya tidak hanya akarakar real tetapi juga akar-akar kompleks, maka untuk mencari akar-akar real maupun kompleks tersebut dapat digunakan metode Muller, metode Birge-vieta, dan lain sebagainya.

Metode Muller dan metode Birge-Vieta masih jarang ditemukan dalam buku-buku atau literasi tentang penyelesaian persamaan polinomial dan kedua metode tersebut dalam penyelesaikan suatu persamaan memerlukan tebakan awal, dimana pada metode Muller memerlukan tiga nilai tebakan awal sedangkan pada metode Birge-Vieta memertukan satu nilai tebakan awal. Pada penelitian sebelumnya yang dilakukan oleh Sindy Fiqih Maulidiyah yang meneliti tentang menentukan akar persamaan polinomial dengan metode Muller, metode Bairstow dan Quontient-difference akan tetapi penelitian tersebut hanya menentukan akar persamaan polinomial dengan cara manual. Maka dari itu penulis tertarik untuk meneliti perbandingan metode Muller dan metode Birge-vieta dalam menyelesaikan persamaan polinomial dengan bantuan program . Adapun bahasa pemrograman yang digunakan oleh penulis untuk membantu penyelesaikan penelitian ini adalah program $\mathrm{R}$.

\section{TINJAUANPUSTAKA}

\section{Polinomial}

Persamaan polinomial merupakan persamaan yang sangat sering ditemui pada 
banyak analisis problem. Bentuk umum dari persamaan ini adalah:

$$
f(x)=a_{0}+a_{1} x+a_{2} x^{2}+\cdots+a_{n} x^{n} \text { (2.1) }
$$

Dengan $a_{i}$ adalah konstanta real, $i=$ $0,1,2, \ldots, n$, dan $a_{n} \neq 0$. Polinomial $f(x)$ memiliki $\mathrm{n}$ buah akar, baik akar nyata maupun akar kompleks. Akar kompleks muncul dalam pasangan konjugasi, $w=u+v i$ dan $w=u-$ vi, dengan $i=\sqrt{-1}$.

Contoh-contoh polinomial berdasarkan derajat polinomial adalah sebagai berikut :

1. Polinomial kuadrat yaitu polinomial dengan nilai pangkat dari suku $x$ adalah dua

$$
f(x)=a x^{2}+b x+c=0
$$

2. Polinomial kubik merupakan polinomial yang nilai pangkat tertinggi dari suku $\mathrm{x}$ adalag tiga $(n=3)$

$$
f(x)=a x^{3}+b x^{2}+c x+d=0
$$

3. Polinomial kuartik adalah polinomial berderajat empat dimana nilai pangkat tertinggi $\mathrm{x}$ adalah empat $(\mathrm{n}=4)$.

$$
f(x)=a x^{4}+b x^{3}+c x^{2}+d x+e=0
$$

4. Polinomial berderajat $n$ merupakan polinomial dengan nilai pangkat tertinggi dari variabel $\mathrm{x}$ adalah $\mathrm{n}$.

$$
\begin{gathered}
f(x)=x^{n}+a_{1} x^{n-1}+a_{2} x^{n-2}+\cdots+ \\
a_{n}=0
\end{gathered}
$$

Dimana $a_{1}, a_{2}, \ldots, a_{n}$ merupakan bilangan real.

\section{Penyelesaian Persamaan Polinomial secara Analitik}

Untuk menyelesaikan soal polinomial terdapat beberapa metode yang sering digunakan yaitu:

1. Metode Pemfaktoran

Persamaan kuadrat adalah persamaan polinomial berderajat 2. Cara memperoleh akar - akar persamaan kuadrat dapat menggunakan metode pemfaktoran.

2. Rumus ABC

Selain dengan menggunakan metode pemfaktoran untuk mencari akar - akar persamaan kuadrat, kita juga bisa menggunakan rumus kuadratis atau biasa juga dikenal dengan nama rumus $A B C$ pada persamaan $a x^{2}+b x+c=0$, dimana $a \neq 0$.

3. Metode Horner

Pencarian akar pada polinomial membutuhkan banyak operasi perkalian. Semakin tinggi derajat polinomial semakin banyak operasi perkalian yang diperlukan.

\section{Metode Numerik}

Metode numerik adalah teknik yang digunakan untuk memformulasikan persoalan matematika sehingga dapat dipecahkan dengan operasi perhitungan/aritmetika biasa (tambah, kurang, kali, dan bagi). Metode artinya cara, sedangkan numerik artinya angka. Jadi metode numerik secara harafiah berarti cara berhitung dengan menggunakan angka-angka.

Dalam menganalisis suatu permasalahan yang didekati dengan menggunakan metode numerik, umumnya melibatkan angka-angka dalam jumlah banyak dan melewati proses perhitungan matematika yang cukup rumit. Namun dengan munculnya berbagai software komputer, masalah tersebut kini dapat diatasi dengan mudah. Akan tetapi pada metode numerik, selalu dihadapkan pada kesalahan atau error yaitu seberapa besar kesalahan yang terjadi dan bagaimana terjadinya proses kesalahan tersebut.

\section{Kompleksitas Algoritma}

Algoritma adalah urutan logis langkahlangkah penyelesaian masalah secara sistematis. Sebuah algoritma tidak saja harus benar, tetapi juga harus mangkus (efisien). Algoritma yang benar sekalipun mungkin tidak berguna untuk jenis dan ukuran masukan tertentu karena waktu yang diperlukan untuk struktur datanya terlalu besar

Kebutuhkan waktu suatu algoritma biasanya dihitung dalam satuan detik, mikrodetik dan sebagainya, sedangkan ruang memori yang digunakannya dapat dihitung dalam satuan byte atau kilobyte. Besarsn yang dipakai untuk menerangkan model abstrak pengukuran waktu/ruang ini adalah kompleksitas algoritma. Ada dua macam kompleksitas algoritma, yaitu kompleksitas waktu dan kompleksitas ruang. Kompleksitas waktu diekspresikan sebagai jumlah tahapan 
komputasi yang butuhkan untuk menjelankan algoritma sebagai fungsi dari ukuran masukan $n$.

\section{Metode Muller}

Metode Muller dapat digunakan untuk mencari sejumlah akar yang dinginkan, real atau kompleks, dari sembarang fungsi dan metode Muller merupakan suatu perluasan dari metode secant.

Prosedur Muller dimulai dengan menuliskan sebuah persamaan kuadrat yang melewati 3 buah titik tersebut, dalam bentuk $a v^{2}+b v+c$. usaha ini akan lebih mudah bila kita mentransformasi sumbu melewati titik tengah (dengan mensubstitusi $v=x-x_{0}$ ), maka kita dapat menulis persamaan parabola yaitu:

$f(x)=a\left(x-x_{2}\right)^{2}+b\left(x-x_{2}\right)+c$

\section{Algoritma Metode Muller}

1. Menentukan nilai awal $x_{0}, x_{1}, x_{2}$

2. Menghitung nilai dari $f\left(x_{0}\right), f\left(x_{1}\right), f\left(x_{2}\right)$.

3. Menghitung nilai

$$
\begin{aligned}
& h_{0}=x_{1}-x_{0} \text { dan } h_{1}=x_{2}-x_{1} \\
& \delta_{0}=\frac{f\left(x_{1}\right)-f\left(x_{0}\right)}{x_{1}-x_{0}} \\
& \delta_{1}=\frac{f\left(x_{2}\right)-f\left(x_{1}\right)}{x_{2}-x_{1}}
\end{aligned}
$$

4. Tentukan $i=2$, karena pada tebakan awal terdiri dari tiga titik, yaitu $x_{0}, x_{1}, x_{2}$, sehingga yang diambil adalah tebakan awal yang terakhir yaitu $x_{2}$

5. Hitunglah

$$
\begin{aligned}
& a=\frac{\left(\delta_{1}-\delta_{0}\right)}{\left(h_{1}+h_{0}\right)} \\
& b=a h_{1}+\delta_{1} \\
& c=f\left(x_{2}\right)
\end{aligned}
$$

6. Menghitung nilai diskriminan

$$
D=\sqrt{b^{2}-4 a c}
$$

Kemudian, jika nilai $|b+D|>|b-D|$, maka rumus yang digunakan adalah

$$
x_{3}=x_{2}+\frac{-2 c}{b+D}
$$

dan jika nilai $|b+D|<|b-D|$, maka rumus yang digunakan adalah

$$
x_{3}=x_{2}+\frac{-2 c}{b-D}
$$

7. Hitung nilai galat dengan rumus:

$$
\varepsilon_{a}=\left|\frac{x_{3}-x_{2}}{x_{3}}\right| 100 \%
$$

Jika $x_{3}$ dan galaknya telah diperoleh $\varepsilon_{a}=$ $\left|\frac{x_{i+1}-x_{i}}{x_{i+1}}\right| 100 \%<$ toleransi, maka iterasinya berhenti. Namun bila $\varepsilon_{a}=$ $\left|\frac{x_{i+1}-x_{i}}{x_{i+1}}\right| 100 \%>$ toleransi, maka iterasinya diulang lagi.

8. Iterasi dilanjutkan lagi dengan cara mengganti nilai $x_{0}$ menjadi $x_{1}, x_{1}$ menjadi $x_{2}$ dan $x_{2}$ menjadi $x_{3}$.

\section{Metode Birge - Vieta}

Metode Birge - Vieta hanya dapat digunakan mencari akar polinomial $f(x)$ dengan derajat $\mathrm{m}$.

\section{Algoritma Metode Birge - Vieta}

1. Menentukan nilai awal

2. Mencari nilai koefisien $b$ dan $c$, yaitu

$$
\begin{aligned}
& b_{j}=a_{j}+x_{n} b_{j+1} \\
& c_{j}=b_{j}+x_{n} c_{j+1}
\end{aligned}
$$

3. Setelah mendapatkan nilai koefisien $b$ dan $c$, maka cari akarnya dengan rumus :

$$
x_{n+1}=x_{n}-\frac{b_{0}}{c_{1}} ; n=0,1,2, \ldots
$$

4. Menghitung nilai error dengan rumus:

$$
x_{n+1}=\left|\frac{x_{n+1}-x_{n}}{x_{n}}\right| 100 \%
$$

Jika $x_{n+1}>$ toleransi, maka iterasi di lanjutkan lagi, dengan menganti nilai tebakan awal $x_{0}$ menjadi $x_{1}$.

5. Melakukan proses iterasi dengan mengulangi langkah pertama sampai keempat sampai didapaatkan nilai error sekecil mungkin

\section{Matematika dalam Perspektif Al-Qur'an}

Matematika dianggap sebagai salah satu ilmu terpenting di peradaban Islam karena merupakan dasar dari semua ilmu, bahasa ilmu pengetahuan, sesuai dengan pemikiran dari Aristoteles. Sementaran itu, Al-Khawarizmi merupakan seorang tokoh yang mengembangkan ilmu matematika ini sehingga namanya melambung dan menjadi matematikawan terkemuka di dunia. 


\section{METODOLOGI}

Jenis penelitian yang digunakan pada penelitian ini ialah penelitian (kepustakaan) kajian pustaka.

Prosedur penelitian ini, langkahlangkah yang dilakukan peneliti adalah sebagai berikut:

1. Mencari masalah matematis persamaan polynomial berderajat 4, 5, 6 dan 7

2. Menyelesaikan masalah pada persamaan polinomial pada poin 1 dengan menggunakan metode Muller.

3. menyelesaikan masalah pada persamaan polinomial pada poin 1 dengan menggunakan metode Birge-Vieta.

4. Membuat program dengan menggunakan bahsa pemprograman bahasa $\mathrm{R}$.

5. Membandingkan hasil metode Muller dan metode Birge-vieta.

\section{PEMBAHASAN}

\section{Hasil Penelitian}

Berdasarkan prosedur penelitian yang dilakukan oleh peneliti dalam menyelesaian persamaan polinomial berderajat 4, 5, 6 dan 7 , diperoleh hasil penelitian sebagai berikut:

1. Adapun persamaan yang digunakan penulis pada penelitian ini yaitu $f(x)=x^{4}-$ $8 x^{3}-36 x^{2}+462 x-1010, f(x)=x^{5}-$ $3.7 x^{4}+7.4 x^{3}-10.8 x^{2}+10.8 x-$ 6.8, $f(x)=0.0004 x^{6}-0.0156 x^{4}+$ $0.25 x^{2}-1$, dan $f(x)=x^{7}-28 x^{6}+$ $322 x^{5}-1960 x^{3}-13132 x^{2}+$ $13068 x-5040$.

2. Meyelesaikan masalah pada persamaan polinomial dengan menggunakan metode Muller

Studi kasus 1(soal Latihan pada buku Komputasi Numerik dengan Matlab karya Ardi Pujiyanta)

Hitunglah akar dari persamaan polinomial berderajat 4 yaitu $f(x)=x^{4}-8 x^{3}-36 x^{2}+$ $462 x-1010$ dengan metode Muller dengan tebakan awal $x_{0}=3.5, x_{1}=4.5$ dan $x_{2}=4$ dan nilai toleransi 0.0001.

\section{Penyelesaian}

\section{Iterasi 1}

a. Menuliskan persamaan polinomial yaitu $f(x)=x^{4}-8 x^{3}-36 x^{2}+462 x-$ 1010

b. Menentukan nilai awal $x_{0}=3.5, x_{1}=$ $4.5, x_{2}=4$

c. Menghitung $\quad f\left(x_{0}\right), f\left(x_{1}\right), f\left(x_{2}\right)$, sehingga menjadi:

$$
\begin{aligned}
& f(3.5)=-26.9375 \\
& f(4.5)=21.0625 \\
& f(4)=6
\end{aligned}
$$

d. Menghitung nilai dari $h_{0}, h_{1}, \delta_{0}$ dan nilai $\delta_{1}$

$h_{0}=x_{1}-x_{0}=4.5-3.5=1$

$h_{1}=x_{2}-x_{1}=4-4.5=-0.5$

$\delta_{0}=\frac{f\left(x_{1}\right)-f\left(x_{0}\right)}{x_{1}-x_{0}}$

$$
=\frac{21.0625-(-26.9375)}{4.5-3.5}
$$

$=48$

$\delta_{1}=\frac{f\left(x_{2}\right)-f\left(x_{1}\right)}{x_{2}-x_{1}}=\frac{6-21.0625}{4-4.5}=30.125$

e. Tentukan $i=2$, karena pada tebakan awal terdiri dari tiga titik, yaitu $x_{0}, x_{1}, x_{2}$, sehingga yang diambil adalah tebakan awal yang terakhir yaitu $x_{2}$

f. Menghitung nilai $\mathrm{a}, \mathrm{b}$ dan $\mathrm{c}$

$$
\begin{aligned}
& a=\frac{\left(\delta_{1}-\delta_{0}\right)}{\left(h_{1}+h_{0}\right)}=\frac{30.125-48}{-0,5+1}=-35.75 \\
& b=a h_{1}+\delta_{1} \\
& =-35.75(-0.5)+30.125 \\
& \quad=48 \\
& c=f\left(x_{2}\right)=6
\end{aligned}
$$

g. Menghitung nilai diskriminan

$$
\begin{aligned}
D & =\sqrt{b^{2}-4 a c} \\
& =\sqrt{48^{2}-4(-35.75)(6)} \\
& =56.23165
\end{aligned}
$$

Kemudian, jika nilai $|b+D|>\mid b-$ $D \mid$, maka rumus yang digunakan adalah

$$
x_{3}=x_{2}+\frac{-2 c}{b+D}
$$

Dan jika nilai $|b+D|<|b-D|$, maka rumus yang digunakan adalah

$$
x_{3}=x_{2}+\frac{-2 c}{b-D}
$$

Karena $|48+56.23166|>\mid 48-$ $56.23166 \mid$, maka rumus yang digunakan adalah

$$
\begin{aligned}
& x_{3}=x_{2}+\frac{-2 c}{b+D} \\
& x_{3}=4+\frac{-2(6)}{48+56.23166}=3.884872
\end{aligned}
$$


h. Menghitung galatnya

$$
\begin{aligned}
\varepsilon_{a} & =\left|\frac{x_{3}-x_{2}}{x_{3}}\right| 100 \% \\
\varepsilon_{a} & =\left|\frac{3.884872-4}{3.884872}\right| 100 \% \\
& =2.9635
\end{aligned}
$$

Karena nilai galak $2.9635>0.0001$, maka iterasi masih dilanjutkan lagi dengan cara menganti nilai $x_{0}$ menjadi $x_{1}, x_{1}$ menjadi $x_{2}$, dan $x_{2}$ menjadi $x_{3}$.

i. Menganti nilai $x_{0}$ menjadi $x_{1}, x_{1}$ menjadi $x_{2}$, dan $x_{2}$ menjadi $x_{3}$. sehingga ketiga nilai tebakan awalnya $x_{0}=3,4, x_{1}=4,5, x_{2}=$ 4 berubah menjadi $x_{0}=4,5 x_{1}=4 x_{2}=$ 3.884872 dengan ketiga nilai tebakan awal tersebut dilakukan iterasi lagi.

\section{Iterasi 2}

a. Menentukan nilai awal $x_{0}=4.5, x_{1}=$ $4, x_{2}=3.884872$

b. Menghitung $\quad f\left(x_{0}\right), f\left(x_{1}\right), f\left(x_{2}\right)$, sehingga menjadi:

$$
\begin{aligned}
& f(4.5)=21.0625 \\
& f(4)=6 \\
& f(3.884872)=0.214911
\end{aligned}
$$

c. Menghitung nilai dari $h_{0}, h_{1}, \delta_{0}$ dan nilai $\delta_{1}$

(i). $h_{0}=4-4.5=-0.5 \quad$ dan

$$
h_{1}=3.884872-4=
$$$$
-0.11513
$$

(ii). $\begin{array}{ll}\delta_{0}=\frac{6-21.0625}{4-4.5}=30.125 \quad \text { dan } \\ & \delta_{1}=\frac{0.214911-6}{3.884872-4}=50.24912\end{array}$

d. Tentukan $i=2$, karena pada tebakan awal terdiri dari tiga titik, yaitu $x_{0}, x_{1}, x_{2}$, sehingga yang diambil adalah tebakan awal yang terakhir yaitu $x_{2}$

e. Menghitung nilai $\mathrm{a}, \mathrm{b}$ dan $\mathrm{c}$

$$
\text { (i). } \begin{aligned}
a & =\frac{\left(\delta_{1}-\delta_{0}\right)}{\left(h_{1}+h_{0}\right)} \\
& =\frac{50.24912-30.125}{-0.11513+(-0,5)}=-32.7153
\end{aligned}
$$

(ii). $b=a h_{1}+\delta_{1}$

$$
=-32.7153(-0.11513)+
$$$$
50.24912=54.01558
$$

(iii). $c=f\left(x_{2}\right)=0.214911$

f. Menghitung nilai diskriminan

$$
D=\sqrt{b^{2}-4 a c}
$$

$$
\begin{aligned}
& = \\
& \sqrt{54.01558^{2}-4(-32.7153)(0.214911)} \\
& =54.27528
\end{aligned}
$$

Kemudian karena |54.01558+ $54.27528|>| 54.01558$ - 54.27528 |, maka rumus yang digunakan adalah

$$
\begin{aligned}
& x_{3}=x_{2}+\frac{-2 c}{b+D} \\
& x_{3}=3.884872+\frac{-2(0.214911)}{54.01558+54.27528}=
\end{aligned}
$$

3.880903

g. Menghitung galatnya

$$
\begin{aligned}
\varepsilon_{a} & =\left|\frac{x_{3}-x_{2}}{x_{3}}\right| 100 \% \\
\varepsilon_{a} & =\left|\frac{3.880903-3.884872}{3.880903}\right| 100 \% \\
& =0.102274
\end{aligned}
$$

Karena nilai galak 0.102274 >0.0001, maka iterasi masih dilanjutkan lagi dengan cara menganti nilai $x_{0}$ menjadi $x_{1}, x_{1}$ menjadi $x_{2}$, dan $x_{2}$ menjadi $x_{3}$.

h. Menganti nilai $x_{0}$ menjadi $x_{1}, x_{1}$ menjadi $x_{2}$, dan $x_{2}$ menjadi $x_{3}$. sehingga ketiga nilai tebakan awalnya $x_{0}=4.5, x_{1}=4, x_{2}=$ 3.884872 berubah menjadi $x_{0}=4 x_{1}=$ $3.884872, x_{2}=3.880903$ dengan ketiga nilai tebakan awal tersebut dilakukan iterasi lagi.

\section{Iterasi 4}

a. Menentukan nilai awal $x_{0}=3.884872$, $x_{1}=3.880903, x_{2}=3.880947$

b. Menghitung $f\left(x_{0}\right), f\left(x_{1}\right), f\left(x_{2}\right)$, sehingga menjadi:

$$
\begin{aligned}
& f(3.884872)=0.214911 \\
& f(3.88093)=-0.00242 \\
& f(3.88947)=1.57 e-07
\end{aligned}
$$

c. Menghitung nilai dari $h_{0}, h_{1}, \delta_{0}$ dan nilai $\delta_{1}$

(i). $h_{0}=-0.00397$ dan $h_{1}=$ $4.41 e-05$

(ii). $\delta_{0}=54.75489$ dan $\delta_{1}=$ 54.90696

d. Tentukan $i=2$, karena pada tebakan awal terdiri dari tiga titik, yaitu $x_{0}, x_{1}, x_{2}$, sehingga yang diambil adalah tebakan awal yang terakhir yaitu $x_{2}$

e. Menghitung nilai $\mathrm{a}, \mathrm{b}$ dan $\mathrm{c}$
(i). $\quad a=\frac{\left(\delta_{1}-\delta_{0}\right)}{\left(h_{1}+h_{0}\right)}=-38.743$
(ii). $\quad b=a h_{1}+\delta_{1}=54.90525$
(iii). $\quad c=f\left(x_{2}\right)=1.57 e-07$ 
f. Menghitung nilai diskriminan

$$
\begin{aligned}
D & =\sqrt{b^{2}-4 a c} \\
& =54.90525
\end{aligned}
$$

Kemudian, karena | $54.90525+$ $1.57 e-07|>| 54.90525-1.57 e-07 \mid$, maka rumus yang digunakan adalah

$$
\begin{aligned}
& x_{3}=x_{2}+\frac{-2 c}{b+D} \\
& x_{3}=3.880947
\end{aligned}
$$

g. Menghitung galatnya

$$
\begin{aligned}
\varepsilon_{a} & =\left|\frac{x_{3}-x_{2}}{x_{3}}\right| 100 \% \\
& =7.39 \mathrm{e}-08
\end{aligned}
$$

Karena nilai galak $7.39 \mathrm{e}-08<$ 0.0001, maka iterasi berhenti.

3. Menyelesaikan masalah pada persamaan polynomial dengan menggunakan metode Birge-Vieta.

Studi kasus 1(soal Latihan pada buku Komputasi Numerik dengan Matlab karya Ardi Pujiyanta)

Hitunglah akar dari persamaan polinomial berderajat 4 yaitu $f(x)=x^{4}-8 x^{3}-$ $36 x^{2}+462 x-1010$ dengan metode Birge-Vieta dengan tebakan awal $x_{0}=$ 3. 5 dan nilai toleransi 0.0001.

\section{Penyelesaian:}

\section{Iterasi 1}

a. Menuliskan persamaan polinomial $f(x)=$ $x^{4}-8 x^{3}-36 x^{2}+462 x-1010$

b. Menentukan nilai awal $x_{0}=3.5$

c. Mencari nilai koefisien $b$ dan $c$

$$
\begin{aligned}
& b_{j}=a_{j}+x_{0} b_{i+1} \\
& c_{i}=b_{j}+x_{0} c_{c+i} \\
& a_{4}=b_{4}=c_{4}=1
\end{aligned}
$$

Jadi $b_{3}=a_{3}+x_{0} b_{4}=-8+3.5 * 1=-4.5$

$$
\begin{aligned}
& c_{3}=b_{3}+x_{0} c_{4}=-4.5+3.5 * 1=-1 \\
& b_{2}=a_{2}+x_{0} b_{3}=-36+3.5 * \\
& (-4.5)=-51.75 \\
& c_{2}=b_{2}+x_{0} c_{3}=-51.75+3.5 * \\
& (-1)=-55.25 \\
& b_{1}=a_{1}+x_{0} b_{2}=462+3.5 * \\
& -51.75=280.875 \\
& c_{1}=b_{1}+x_{0} c_{2}=280.875+3.5 * \\
& (-55.25)=87.5 \\
& b_{0}=a_{0}+x_{0} b_{1}=-1010+3.5 * \\
& 280.875=-26.9375
\end{aligned}
$$

d. Menghitung akarnya

$$
\begin{aligned}
x_{1} & =x_{o}-\frac{b_{0}}{c_{1}} \\
x_{1} & =3.5-\frac{(-26.9375)}{87.5} \\
& =3.807857
\end{aligned}
$$

e. Menghitung nilai error

$$
\begin{aligned}
x_{1} & =\left|\frac{x_{1}-x_{0}}{x_{1}}\right| 100 \% \\
x_{1} & =\left|\frac{3.807857-3.5}{3.807857}\right| 100 \% \\
& =8.084787
\end{aligned}
$$

Karena $8.084787>0.0001$, maka iterasi di lanjutkan dengan menganti nilai tebakan awal $x_{0}=3.5$ menjadi $x_{1}=3.807857$

f. Melakukan proses iterasi dengan mengulangi langkah pertama sampai ketiga sampai didapatkan nilai error sekecil mungkin.

\section{Iterasi 2}

a. Menentukan nilai awal $x_{0}=3.807857$

b. Mencari nilai koefisien $b$ dan $c$

$a_{4}=b_{4}=c_{4}=1$

$b_{3}=a_{3}+x_{0} b_{4}=-4.19214$

$c_{3}=b_{3}+x_{0} c_{4}=-0.38429$

$b_{2}=a_{2}+x_{0} b_{3}=-51.9631$

$c_{2}=b_{2}+x_{0} c_{3}=-53.4264$

$b_{1}=a_{1}+x_{0} b_{2}=264.132$

$c_{1}=b_{1}+x_{0} c_{2}=60.69196$

$b_{0}=a_{0}+x_{0} b_{1}=-4.22304$

c. Menghitung akarnya

$$
\begin{aligned}
x_{2} & =x_{1}-\frac{b_{0}}{c_{1}} \\
x_{2} & =3.807857-\frac{(-4.22304)}{60.69196} \\
& =3.877439
\end{aligned}
$$

d. Menghitung nilai error

$$
\begin{aligned}
x_{2} & =\left|\frac{x_{2}-x_{1}}{x_{2}}\right| 100 \% \\
& =1.794522
\end{aligned}
$$

Karena $1.794522>0.0001$, maka iterasi di lanjutkan dengan menganti nilai tebakan awal $x_{1}=3.133333$ menjadi $x_{2}=$ 3.877439

e. Melakukan proses iterasi dengan mengulangi langkah pertama sampai ketiga sampai didapatkan nilai error sekecil mungkin.

\section{Iterasi 5}

a. Menentukan nilai awal $x_{2}=3.081832$

b. Mencari nilai koefisien $b$ dan $c$

$$
a_{4}=b_{4}=c_{4}=1
$$




$$
\begin{aligned}
& b_{3}=a_{3}+x_{0} b_{4}=-4.11905 \\
& c_{3}=b_{3}+x_{0} c_{4}=-0.23811 \\
& b_{2}=a_{2}+x_{0} b_{3}=-51.9858 \\
& c_{2}=b_{2}+x_{0} c_{3}=-52.9099 \\
& b_{1}=a_{1}+x_{0} b_{2}=260.2458 \\
& c_{1}=b_{1}+x_{0} c_{2}=54.90525 \\
& b_{0}=a_{0}+x_{0} b_{1}=-2.9 e-09
\end{aligned}
$$

c. Menghitung akarnya

$$
\begin{aligned}
x_{3} & =x_{2}-\frac{b_{0}}{c_{1}} \\
& =3.880947
\end{aligned}
$$

d. Menghitung nilai error

$$
\begin{aligned}
& x_{3}=\left|\frac{x_{3}-x_{2}}{x_{3}}\right| 100 \% \\
= & 1.36 e-09
\end{aligned}
$$

Karena $1.36 e-09<0.0001$, maka iterasi dihentikan.

Berdasarkan hasil penelitian yang diperoleh, maka dapat diketahui hasil Metode Muller dan Metode Birge-Vieta berdasarkan galat dan iterasinya, untuk menentukan akarakar persamaan polinomial dan waktu komputasinya. Adapun persamaan polinomial yang digunakan yaitu persamaan polinomial berderajat 4, 5, 6 dan 7 .

Dengan menggunaka bantuan program R, penyelesaian Metode Muller dilakukan dengan menginput nilai tebakan awal yaitu $x_{0}, x_{1}$ dan $x_{2}$, dan nilai batas toleransi, sedangankan penyelesaian Metode Birge-Vieta dilakukan dengan menginput jumlah suku, nilai tebakan awal, nilai batas toleransi dan nilainilai dari konstanta persamaan. Kemudian selanjutnya akan diproses oleh komputer dan menghasilkan banyaknya iterasi, akar-akar persamaan, nilai galat terkecil dan waktu komputasi.

Pada metode Muller dengan tebakan awal 3.5, 4.5 dan 4 dengan batas toleransi 0.0001 . diperoleh hasil komputasi, pada persamaan yang berderajat 4 akar yang diperoleh adalah 3.880947 dengan jumlah iterasi 4, dengan galat $7.4 e-08$ dan waktu komputasi 0.21 . Pada metode Birge-Vieta dengan tebakan awal 3.5 dengan batas toleransi 0.0001 diperoleh hasil komputasi, pada persamaan yang berderajat 4 akar yang diperoleh adalah 3.880947 dengan jumlah iterasi 5 , galatnya $1.36 e$ - 09 dan waktu komputasi 0.17 .
Adapun hasil penelitian menunjukkan perbandingan antara metode Muller dan metode Birge-Vieta. Jika dilihat dari jumlah iterasi pada persamaan berderajat 4 dan 7 metode muller membutuhkan iterasi yang sedikit sedangkan metode Birge-Vieta membutuhkan iterasi yang lebih banyak. Sedangkan pada persamaan 5 dan 6 metode Muller membutuhkan iterasi yang lebih banyak sedangkan metode Birge-Vieta membuthkan iterasi yang sedikit. Jika dilihat dari segi akar, metode Muller memperoleh akar berupa bilang real dan komplek sedangkan pada metode Birge-Vieta memperoleh akar beruba bilangan real saja. Jika dilihat dari segi galat terkecil pada persamaan berderajat 4, 5 dan 6 metode Muller galatnya masih besar sedangkan metode Birge-Vieta galatnya kecil, tapi pada persamaan 7 metode Muller galatnya kecil sedangkan metode Birge-Vieta galatnya masih besar. Jika dilihat dari segi waktu komputasi metode Muller membutuhkan waktu komputasi yang panjang sedangkan metode Birge-Vieta membutuhkan waktu komputasi yang pendek.

\section{KESIMPULAN}

Berdasarkan hasil dan pembahasan pada bab sebelumnya, maka dapat diambil beberapa kesimpulan yaitu dari hasil output program $\mathrm{R}$ metode Muller dengan galat 0.0001 dan nilai tebakan awal yaitu 3.5, 4.5 dan 4. Dan metode Birge-Vieta nilai tebakan awal yaitu 3.5. Jika dilihat dari jumlah iterasi pada persamaan berderajat 4 dan berderajat 7 pada metode Muller membutuhkan iterasi yang sedikit, sedangkan pada metode Birge-Vieta membutuhkan iterasi yang lebih banyak, dan pada persamaan berderajat 5 dan 6 pada metode Muller membutuhkan iterasi yang lebih banyak sedang pada metode Birge-Vieta membutuhkan iterasi yang pendek.

Jika dilihat dari akar yang di peroleh pada persamaan berderajat 4 dan berderajat 7 metode Muller dan metode Birge-Vieta memperoleh nilai akar yang sama dan pada persamaan berderajat 5 dan 6 pada metode Muller akarnya yang diperoleh berupa bilang real dan komplek sedangkan pada metode Birge-Vieta akar yang diperoleh berupa bilangan real. Jika dilihat dari 
kecil galatnya pada persamaan berderajat 4 , berderajat 5 dan berderajat 6 pada metode Muller galatnya masih besar sedangkan pada metode Birge-Vieta galatnya kecil dan pada persamaan berderajat 7 pada metode Muller galatnya kecil sedangkan pada metode BirgeVieta galatnya masih besar. Jika dilihat dari waktu komputasi pada metode Muller membutuhkan waktu komputasi yang panjang sedangkan pada metode Birge-Vieta membutuhkan waktu komputasi yang pendek.

\section{DAFTAR PUSTAKA}

[1] Agama, Departemen RI. Al-Qur'an dan Terjemahannya. Semarang: PT. Kumudasmoro Grafindo, 1994).

[2] A.Salusu. Metode Numerik Dilengkapi dengan Animasi Matematika dan Panduan Singkat Maple. Yogyakarta: Graha Ilmu. 2008.

[3] Basuki, Achmad dan Nana Ramadijanti. Metode Numerik dan Algoritma Komputasi. Yogyakarta: Andi, 2005.

[4] Chapra dan Canale. Numerical Methods for Engineers. New York: McGraw_Hill Education, 2015

[5] Chapra, Steven c. dan Raymond P. Canale. metode numerik untuk teknik dengan Penerapan pada komputer PribadI. Jakarta: UI-Press, 1991.

[6] D. Conte, Samuel. Dasar-dasar Analisis Numerik suatu pendekatan Algoritma. Jakarta: Erlangga. 1980.

[7] Howard, II, james P. Computational Methods for Numerical Analysis With R. Francis: CRC Press. 2017.

[8] Karim, Abdul. Renaisans Islam. Jakarta: PT Elex Media Komputindo, 2015

[9] Kosasih, Bayung. Komputasi Numerik Teori dan Aplikasi. Yogyakarta: Andi, 2006.

[10] Munir, Rinaldi. Matematika Diskrit. Bandung: Informatika. 2005.

[11] Munir, Rinaldi. Metode numerik. Bandung: Informatika. 2013.

[12] Mustafa Al-Maragi, Ahnmad. Terjemah Tafsir Al-maragi JUS: 28, 29 dan 30. Semarang: CV Toha Putra. 1993.
[13] Pujiyanta, Ardi. Komputasi Numerik dengan Matlab. Yogyakarta: Graha Ilmu. 2007.

[14] Rahman,Hairur. Indahnya Matematika dalam Al-Qur'an. Malang: UIN-Malang Press, 2007.

[15] Rahmah, Yaniar dan dkk. Development of Calculator for Finding Complex Roots of $n^{\text {th }}$ Degree Polymials (Surakarta: Vol. 5, No. 2, Desember 2016)

[16] Rosadi, Dedi. Analisis Statistika dengan R. Yogyakarta: Gadjah Mada University Press, 2015.

[17] Shihab, M. Quraish. Tafsir al-Mishbah volume 7. Jakarta: Lentera Hati, 2002.

[18] Sangadji, Merode Numerik .Yogyakarta; Graha Ilmu, 2008

[19] Setiawan, Agus. Pengantar Metode Numerik. Yogyakarta: Andi. 2007. 